mistake is not their own. The advice of Francis Galton, "Never resent criticism and never reply to it", is good, though hard to follow by those not possessing Galton's saintly disposition and philo. sophical calm.

\section{Statistics and Inductive Inference}

IN a paper read before the Royal Statistical Society on December 18, Prof. R. A. Fisher surveyed the recent change in the outlook of mathematical statisticians. The most profound modification seems to have taken place rather in the logical than in the mathematical aspect, though it has been brought about by the resolution of mathematical difficulties. Statisticians are now dealing with types of uncertain inference wider than those of the theory of probability. Prof. Fisher expressed the view that the current teaching of pure mathematics is not an altogether adequate preparation for fruitful work in this field, for this teaching is purely deductive, omitting the essential concepts of inductive logic, and insists on 'rigour' in a limited sense which he considers very inadequate to the requirements of an inductive problem. The questions raised by Prof. Fisher are of great interest and importance, but it should not be overlooked that there is still some difference of opinion concerning them, as will be seen by a perusal of the series of papers in the Proceedings of the Royal Society (1932-4) by Dr. H. Jeffreys.

\section{Early Man in North America}

Dr. Frank H. H. Roberts, JR., according to a communication issued by the Smithsonian Institution, Washington, D.C., has discovered in the foothills of the Rocky Mountains, in northern Colorado, a habitation site and factory of 'Folsom' man. This discovery is of the greatest importance for American archæology, as not only is it the oldest known habitation site in America, but it is also the first occasion upon which there has been any indication of the mode of life of the peoples by whom the 'Folsom' points were made, beyond the bare fact that they were hunting tribes of a high antiquity -a deduction from the association of these points with the bones of extinct bison, musk ox and mammoth, known to have pastured at the edge of the ice-sheet. The 'Folsom' points, it will be remembered, were first discovered five years ago at Folsom in New Mexico, and since then these finelychipped flint implements have been found, frequently in association with extinct mammals, all over the United States from New Mexico to Virginia and Pennsylvania. It is thought by some authorities that they point to the existence of man in America several thousand years earlier than had previously been supposed. Dr. Roberts's discovery provides something of a cultural background for these scattered finds. The site he has now discovered rests upon a hard, chalk-like formation with about fifty feet of alluvial deposits above it. These must have been laid down very slowly. It is about a quarter of a mile in extent, but as yet only a small part has been excavated. The relics represent several camp sites occupied over a period of years. Flint nodules from which the implements were manufactured are plentiful. Thirty characteristic points and a great variety of scrapers, rough stone blades, drills, engraving tools and hammerstones, with a large number of broken animal bones, have been collected.

\section{Antiquity}

WrтH its December issue, Antiquity completes its eighth year. The editor of the only free-lance journal entirely devoted to archæological matters is to be congratulated on his success in having carried through this enterprise successfully and without the assistance of any official organisation, in a period of exceptional difficulty. While there is undoubtedly a considerable public which is interested in archæological discovery up to a point, to hold that interest requires both tact and judgment. The editor, whose aim is to present to his readers scientifically sound and accurate information of the latest movements in archæological discovery in a popular form, has a difficult course to steer, if he is to avoid the appeal to the sensationalism which flavours the news of 'finds' as it appears in most of the daily Press. On the other hand, the editor of Antiquity, both by his own 'tilting' in his unconventional notes and otherwise, encourages his contributors to an engaging freedom of treatment which in itself adds no little attraction to the pages of his periodical. The contents of Antiquity of December illustrate these qualities admirably. If, for example, Mr. Noel Myres' criticism of Dr. Mortimer Wheeler's article in a previous issue on the topography of Saxon London ventilates further a subject which is of perennial interest to a wide circle, Dr. Wheeler's reply will appeal equally to those who appreciate learning worn lightly. Among the remaining contents of this issue, which are as a whole no less attractive, it is, perhaps, permissible to refer to the contribution by Sir George Macdonald on the Romans in the Middle East, which is an illuminating commentary on M. A. Poidebard's recently published air survey of the Roman frontier in Syria. Like its predecessors, this issue fully supports the editor's appeal for an extended circulation to ensure the continued existence of a publication which is doing excellent work for archæological science by keeping its achievement before a wider public than is reached through channels of a more formal nature.

\section{Thermo-remanence of Bricks}

A LETTER has been received from Mr. T. G. Bocking, Princes Chambers, 6 Corporation Street, Birmingham, 2, giving an account of some observations on the magnetic properties of bricks. Bricks were selected from a number of South Staffordshire kilns, the direction in which the bricks were lying when baked being noted. The polarity was most clearly marked when the bricks had been lying in a north-south direction, and it was found that the bricks were magnetised approximately along the line of magnetic dip. Among the bricks examined were 
some made from Etruria marl, containing about 11 per cent iron oxide. The kiln temperature was $1150^{\circ} \mathrm{C}$. The content of iron oxide (mainly $\mathrm{Fe}_{2} \mathrm{O}_{3}$ ), to which such ferromagnetic properties may be attributed, varies considerably in the materials from which bricks are made. It is usually well below 2 per cent in the fire-clays giving white and cream bricks, about 7 per cent in the clays giving red bricks, and 10 per cent or more in those giving blue and black bricks. Among recent relevant investigations are those of Koenigsberger (Phys. Z., 33, 468; 1932) on hæmatite $\left(\mathrm{Fe}_{2} \mathrm{O}_{3}\right)$, magnetite $\left(\mathrm{Fe}_{3} \mathrm{O}_{4}\right)$ and other ferromagnetic compounds. He finds that hæmatite, when cooled down in the earth's vertical field $(0.4$ gauss) from above the Curie point (about $670^{\circ} \mathrm{C}$.), shows a residual magnetisation which approaches the saturation remanence, and may be a considerable fraction of the saturation magnetisation. It is, of course, not possible to generalise about bricks. Each set of bricks presents a special problem, and precise discussion of the magnetic properties would require a detailed knowledge of the chemical composition of the clays, and of the conditions of baking and cooling. It is, however, probably not widely realised that most bricks are magnets-though feeble ones; and Mr. Bocking's observations are of interest in indicating that the phenomenon of thermo-remanence may be demonstrated with such a common object as an ordinary brick.

\section{A Remarkable Cloud Form}

A PHotograph of a remarkable cloud, of which a reproduction is shown in Fig. 1, has been received from Prof. I. S. Astapowitsch, of the Astronomical Institute, Fontanka 34, Leningrad. It was observed some time in 1932 at Stalinabad (lat. $38^{\circ} 34^{\prime}$ N., long. $68^{\circ} 47^{\prime}$ E.) above the Hissar Valley, and is described as having a rotational movement. Rotation round a vertical axis is strongly suggested by the appearance in the photograph of the middle and upper parts of the cloud. Students of cloud.

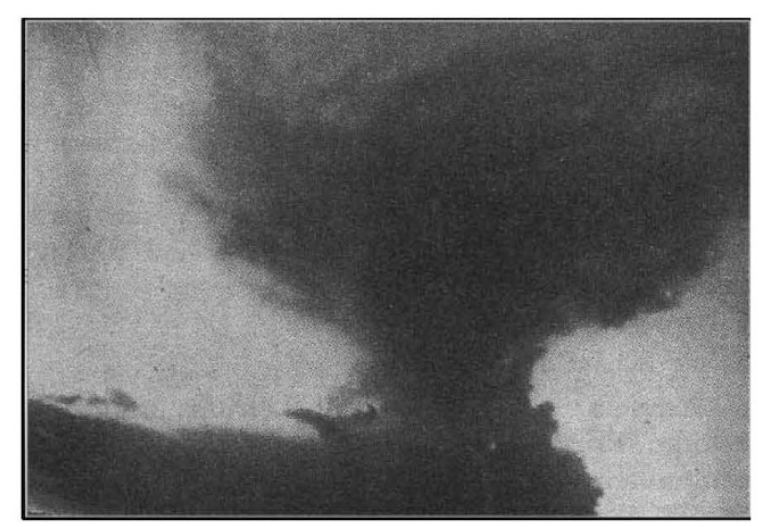

FIG. 1.

forms will recognise at once the very unusual character of this cloud, which has some structural resemblance both to the cumulo-nimbus cloud associated with a thunderstorm and to the funnel cloud of the tornado. By a curious coincidence, in a recent number of the Meteorological Magazine (Nov. 1934, vol. 69, No. 826) a sketch is shown of a cloud observed on October 4, 1934, near Waltham Cross, Hertfordshire, by Mr. Donald L. Champion, which has strong points of resemblance to the cloud just described. In each case a strong upward growth appears to have taken place over one part of a rather flattened cumulus cloud, the base of which was inclined to be convex, the central parts appearing to be lower than those farther from the centre. In the cloud near Waltham Cross the rapid vertical extension was formed in a few seconds, and after about five minutes the mushroom-shaped top spread out horizontally to form an 'anvil' cloud like those so often seen over thunder clouds. In both cases it is likely that opposed wind currents and convexion, perhaps associated with local heating, may have combined to produce rapid ascent of air with otation.

\section{Distribution of Birds at Sea}

Mos' ocean travellers must have noticed the very irregular distribution of birds on the open sea on different days, notwithstanding the apparently similar conditions of air and ocean. Censuses made during the crossing of the Atlantic record statistically these differences, but little attempt has been made to suggest a satisfactory reason for them. It seems very likely, however, that the presence or absence of pelagic birds is regulated by the oceanic currents, as S. C. Brooks suggests in the Condor (September 1934, p. 185). Oceanographers have shown that where the Arctic Current meets the North Atlantic Drift, there arise complexes of eddies and upwelling of the under waters, and that at the margin of contact there is a surface display of abundant organisms which attract fishes and other predators. This congregation of plenteous foodstuffs in limited areas may well attract pelagic birds, and Jesperson has already shown that there is a general connexion between the numbers of birds seen in a particular area at sea, and the quantity of macro-plankton in the surface waters. Pushing the probabilities further, it is likely that the migrations of oceanic birds may be related to the movements of plankton, by whatever determined, and tentatively Brooks makes the very interesting (but quite untested) suggestion that one of the factors which guided the homing terns of Bird Key from Cape Hatteras, to which they had been conveyed, back to the Tortugas, may have been the rich feeding grounds along the margin of the Gulf Stream. He adds that perhaps other factors too must be considered, such as the density of the air, which has been regarded as determining the northern limit of the distribution of the southern Atlantic wandering albatross.

\section{Flora of West Lancashire Dunes}

For some time, increasing concern has been felt amongst the botanists and Nature-lovers of this area for the dangerous position of the unique flora of the dunes of west Lancashire, particularly around Ainsdale. Recently two representatives of the Flora's League-a society for the preservation of wild flowers- 